\title{
Cutting edge of COPD therapy: current pharmacological therapy and future direction
}

\author{
Mitsuhiro Yamada and Masakazu Ichinose*
}

\begin{abstract}
Chronic obstructive pulmonary disease (COPD) is a common global health problem with increasing incidence and mortality. Therefore, attempting to increase the awareness of COPD and disseminate an effective system of management for COPD is important for human health. The management of stable COPD should be based on the disease severity, which is assessed by the severity of airflow limitation, symptoms and risk of exacerbations. The current mainstay of COPD therapy is bronchodilators. Recent advances in the development of both long-acting muscarinic receptor antagonists (LAMAs) and long-acting $\beta_{2}$-adrenergic receptor agonists (LABAs) enable us to not only improve lung function, symptoms and quality of life, but also decrease the frequency of exacerbations and curb the rate of progression of airflow limitation. Because there are clinical phenotypes of COPD which have increased airway inflammation, inhaled corticosteroids are likely considered for a supplemental medicine added to an optimal long-acting inhaled bronchodilator regimen for frequent exacerbators and patients with the overlap COPD-asthma phenotype. To establish novel COPD therapies that can considerably reduce the disease progression and mortality as well as the comorbidities associated with COPD, new therapeutic targets that are involved in the pathophysiology of COPD are being investigated.
\end{abstract}

Keywords: COPD, Bronchodilators, LAMA, LABA, Inhaled corticosteroids, ICS/LABA, Anti-inflammatory treatment

\section{Introduction}

Chronic obstructive pulmonary disease (COPD) is a major global health issue with constantly increasing incidence and mortality. It is estimated that about $7 \%$ of all individuals have COPD. Especially, the prevalence is up to $10 \%$ in adults aged older than 65 years [1-5]. The actual prevalence would seem to be higher than that reported because COPD is greatly under-diagnosed as well as under-recognized. COPD is expected to become the third leading cause of death worldwide by 2020 [6].

COPD is associated with a chronic inflammatory response in the peripheral airways and lung parenchyma to long-term exposure of noxious particles or gases. In the majority of COPD cases, noxious agents in cigarette smoke cause this chronic inflammation. Its pulmonary component is characterized by airflow limitation that is not thoroughly reversible and usually progressive. The

\footnotetext{
* Correspondence: ichinose@rm.med.tohoku.ac.jp

Department of Respiratory Medicine, Tohoku University Graduate School of Medicine, 1-1 Seiryoumachi, Aobaku, Sendai 980-8574, Japan
}

airflow limitation is caused by increased resistance of the small conducting airways and increased compliance of the lung as a result of emphysematous lesions [7].

The main symptoms of COPD are dyspnea and chronic sputum production. Exertional dyspnea is the usual early symptom of COPD. Although various factors are involved in causing dyspnea, airway narrowing is a cardinal factor associated with dyspnea [8-10]. Airway narrowing in COPD is mainly caused by wall thickening and fibrosis in the small airways, as well as collapse of the small airways during exhalation due to the loss of radial traction caused by breakdown of the lung alveolar tissue $[11,12]$. The increased sputum production is due to the increase in goblet cells and mucus gland hyperplasia [13].

Because COPD cases have an irreversible airflow limitation and their pathological condition is usually progressive throughout life, both pharmacological therapy and nonpharmacologic therapies should aim to control symptoms, improve quality of life, improve exercise tolerability, prevent exacerbations, disease progression and 
comorbidities as well as improve the prognosis. Especially, the recent report shows that dyspnea is the most relevant factor inducing disability, decreasing dyspnea is important to improve the ability of COPD patients [14]. To achieve these goals, both pharmacological therapy and non-pharmacologic interventions including smoking cessation, reduction of other risk factors, vaccinations, oxygen therapy, and pulmonary rehabilitation should be conducted with appropriate assessments of the disease severity at the beginning of a patient's treatment as well as continuous evaluation to determine whether the patient has achieved an adequate response to therapy. Recent observations have supported the hypothesis that, in COPD patients, the "spill-over" of inflammatory mediators from the lungs into the circulation may cause systemic inflammation, which may initiate and worsen ischaemic heart disease, heart failure, osteoporosis, normocytic anaemia, lung cancer, depression and diabetes [15]. Therefore, appropriate control of the comorbidities is also important for COPD patients [16, 17].

In this review, we provide an overview of the current pharmacological therapies for the clinical management of COPD, together with recent advances in long-acting bronchodilators. We also discuss novel therapeutic targets for the future pharmacological therapy of COPD.

\section{Review \\ Current pharmacological therapy for COPD (1) Bronchodilators}

Bronchodilators are the main pharmacological therapy for patients with COPD. Bronchodilators should be added according to the patient's symptoms, risk of frequent exacerbations and severity of the airflow limitation. Bronchodilators can induce long-term improvements in symptoms and exercise capacity, even if there is no or only minimal spirometric improvement, because inhaled bronchodilators reduce dynamic hyperinflation during exercise in patients with COPD, resulting in improved exercise endurance [18]. Moreover, the recent report suggests that the effects of bronchodilators should be evaluated from the changes of airway resistance in the resting tidal volume range rather than $\mathrm{FEV}_{1}$, especially in connection with the improvement of dyspnea [19]. Therefore, the effect of therapies should be determined based on not only forced expiratory volume in one second $\left(\mathrm{FEV}_{1}\right)$ but also decreasing airway resistance and improvement of hyperinflation, symptoms, health-related quality of life (QOL), exercise endurance and physical activity of the patients.

Bronchodilators can be administered by inhalation, orally, percutaneously, subcutaneously, or intravenously. Inhalation is the recommended delivery method for COPD patients because this way maximizes the bronchodilator's effect on the airways while minimizing systemic side effects. Delivery methods for inhalation include a metered dose inhaler (MDI), soft mist inhaler (SMI), dry powder inhaler (DPI) or nebulizer. MDIs, SMIs, and DPIs enable COPD patients to receive inhalation therapy more simply, improving compliance and reducing the need for additional medication. The choice of a delivery method for inhalation should be determined after careful evaluation of the COPD patient's clinical condition (degree of airway obstruction, comorbidities) as well as their ability to maneuverer an inhalation device and to generate sufficient inspiratory flow. These patient factors should be adjusted with the advantages and limitations of each inhaler [20].

Bronchodilators include $\beta_{2}$ agonists, anticholinergics, and also methylxanthine, which is not typically used these days. Because each bronchodilator has a different mechanism of action, the addition of other bronchodilators can be considered when monotherapy is inadequate to improve the symptoms of COPD patients. $\beta_{2}$ agonists activate $\beta_{2}$-adrenergic receptors on airway smooth muscle [21]. Because $\beta_{2}$-adrenergic receptors are coupled to a stimulatory $G$ protein of adenylyl cyclase, this activation increases the intracellular level of cAMP, resulting in decreased calcium concentrations within cells and the activation of protein kinase A. Those changes inactivate myosin light chain kinase and activate myosin light chain phosphatase. Moreover, $\beta_{2}$-agonists open large conductance calcium-activated potassium channels, which induces hyperpolarization of the airway smooth muscle cells. These changes lead to smooth muscle relaxation and bronchodilation. Anticholinergics (muscarinic receptor antagonists (MRAs)) block the activity of the muscarinic acetylcholine receptor $M_{3}$ on smooth muscle cells and submucosal glands [22]. This reduces smooth muscle contraction and mucus secretion, resulting in bronchodilation. A methylxanthine is a competitive, nonselective phosphodiesterase inhibitor that increases the intracellular cAMP level and activation of protein kinase A, resulting in smooth muscle relaxation and bronchodilation [23].

\section{(a) Short-acting bronchodilators}

Short-acting $\beta_{2}$ agonists and anticholinergics can be used for COPD patients with mild intermittent symptoms $[24,25]$. The onset of action by short-acting beta agonists is relatively rapid compared to anticholinergics, whereas the maximal efficacy of short-acting anticholinergics for bronchodilation in COPD patients is better than that of $\beta_{2}$ agonists. Combination therapy may be better because the combined use of a short-acting beta agonist with a short-acting anticholinergic achieves a greater bronchodilator response than either one alone [26], though monotherapy with a short-acting bronchodilator is also effective and acceptable. 
Table 1 Summary of long-acting bronchodilators including combinations

\begin{tabular}{|c|c|c|c|}
\hline & Dosing & Reported superiority over other long-acting bronchodilators or ICSS & References \\
\hline \multicolumn{4}{|l|}{ LAMAs } \\
\hline Tiotropium & once-daily & $\begin{array}{l}\text { vs. salmeterol: trough } \mathrm{FEV}_{1} \text {, improving dyspnea, health-related } \mathrm{QOL} \text {, } \\
\text { preventing exacerbations }\end{array}$ & $27-40$ \\
\hline Glycopyrronium & once-daily & & 41,42 \\
\hline Aclidinium & twice-daily & & 43,44 \\
\hline \multicolumn{4}{|l|}{ LABAs } \\
\hline Salmeterol & twice-daily & & $46-48$ \\
\hline Formoterol & twice-daily & & 49 \\
\hline Indacaterol & once-daily & vs. salmeterol or formoterol: trough FEV1 and improving dyspnea & $50-53$ \\
\hline Olodaterol & once-daily & vs. formoterol: health-related QOL & $54-56$ \\
\hline \multicolumn{4}{|l|}{ LABA/LAMA } \\
\hline Umeclidinium & once-daily & vs. umeclidinium or vilanterol: trough $\mathrm{FEV}_{1}$, improving dyspnea, health-related $\mathrm{QOL}$ & $60-63$ \\
\hline \multicolumn{4}{|l|}{-Vilanterol } \\
\hline Indacaterol & once-daily & vs. tiotropium: trough $\mathrm{FEV}_{1}$, improving dyspnea, health-related $\mathrm{QOL}$, preventing & $64-66$ \\
\hline -Glycopyrronium & & $\begin{array}{l}\text { exacerbations; vs. glycopyrronium: trough } \mathrm{FEV}_{1} \text {, health-related QOL, preventing } \\
\text { exacerbations; vs. indacaterol: trough } \mathrm{FEV}_{1} \text {, improving dyspnea }\end{array}$ & \\
\hline \multicolumn{4}{|l|}{ LABA/ICS } \\
\hline $\begin{array}{l}\text { Fluticasone } \\
\text {-Salmeterol }\end{array}$ & twice-daily & $\begin{array}{l}\text { vs. salmeterol or fluticasone: trough } \mathrm{FEV}_{1} \text {, health-related } \mathrm{QOL} \text {, preventing } \\
\text { exacerbation }\end{array}$ & $48,76,77$ \\
\hline Budesonid & twice-daily & vs. formoterol: trough $\mathrm{FEV}_{1}$, improving dyspnea, health-related $\mathrm{QOL}$, preventing & 78,79 \\
\hline -formoterol & & exacerbatıor & \\
\hline $\begin{array}{l}\text { Fluticasone furoate } \\
\text {-Vilanterol }\end{array}$ & once-daily & vs. fluticasone furoate: trough $\mathrm{FEV}_{1}$ & 80 \\
\hline
\end{tabular}

\section{(b) Long-acting bronchodilators (Table 1)}

(b)-1 Long-acting anticholinergics The long-acting anticholinergics (long-acting muscarinic agents (LAMAs)) include tiotropium, glycopyrronium, aclidinium and umeclidinium. These agents have higher selectivity for M3 receptors than for M2 receptors and dissociate more slowly from the M3 receptors, which can provide longer-lasting bronchodilation [27-29].

Tiotropium is a once-daily long-acting anticholinergic agent with M1 and M3 selectivity, and has been the most studied agent for COPD. Studies have shown that tiotropium improved lung function (an increase of both trough $\mathrm{FEV}_{1}$ and forced vital capacity (FVC)) and exercise endurance as well as health-related QOL, and reduced dyspnea and the risk of COPD exacerbations [30-36]. Studies have also suggested that tiotropium may slow the rate of decline in FEV1 in patients with moderate COPD [37-39]. In terms of safety issues, there is conflicting evidence of adverse cardiovascular effects from tiotropium. Recent meta-analyses suggested that the tiotropium Soft Mist Inhaler (Respimat ${ }^{\circ}$ ) was associated with a significantly increased risk of mortality [40, 41]. This risk was apparent for cardiovascular death in patients with severe COPD, and at a higher daily dose [41]. However, data from a long-term, randomized trial showed that tiotropium was superior in reducing all causes of mortality by
$11 \%$ compared with placebo [42]. Another more recent randomized, double-blind, parallel-group trial revealed no safety issues with the device, supporting the safety of the Soft Mist Inhaler device [43].

Glycopyrronium is a once-daily long-acting anticholinergic agent that also selectively inhibits muscarinic receptors with M1 and M3 selectivity [27]. It also significantly improves lung function (through $\mathrm{FEV}_{1}$ ) and dyspnea and reduces exacerbations of COPD $[44,45]$.

Aclidinium is a twice-daily long-acting anticholinergic that selectively inhibits M3 muscarinic receptors [28]. Since aclidinium is shorter acting than tiotropium, twice-daily dosing is needed for better efficacy. Several trials showed significant improvements in the trough and peak $\mathrm{FEV}_{1}$ [46]. Aclidinium also improves dyspnea and delayed the time to first exacerbation compared to the placebo control $[46,47]$.

Umeclidinium is a once-daily LAMA that acts preferentially on muscarinic M3 receptors, similar to tiotropium. It significantly increases the trough $\mathrm{FEV}_{1}$ and also reduces rescue SABA use [48]. Umeclidinium was been developed for use in a combination inhaler with longacting LABA vilanterol.

(b)-2 Long-acting $\boldsymbol{\beta}_{2}$-agonists The long-acting $\beta_{2}$-agonists (LABAs) include salmeterol, formoterol, indacaterol, 
olodaterol and vilanterol. Until recently, a long-acting anticholinergic was preferred over a long-acting $\beta_{2^{-}}$ agonist because LAMAs, which act effectively for $24 \mathrm{~h}$ by once daily dosing, seemed to be superior to LABAs, which required twice-daily dosing for better effects. Now that daily LABAs are available, the initial selection of a long acting bronchodilator is based on co-morbidities and side effects.

Salmeterol and formoterol are twice-daily LABAs used in the maintenance for COPD. Formoterol has a faster onset of action than salmeterol, and has also been demonstrated to be more potent. Both salmeterol and formoterol significantly improved lung function as well as dyspnea, decreased exacerbation rates and improved health-related quality of life compared to placebo [49-52].

Indacaterol is a once-daily LABA with a rapid onset and 24-h duration of bronchodilation. Indacaterol's long duration of action may be related to its high affinity for the lipid raft domain of the cell membrane [53]. Randomized controlled trials showed that indacaterol significantly improved the trough $\mathrm{FEV}_{1}$ [54-56]. Indacaterol improved dyspnea and decreased the rate of exacerbations in COPD patients. The trials also showed that once-daily indacaterol was significantly more effective than twice-daily salmeterol or formoterol in terms of improving the lung function and reducing dyspnea $[54,56]$.

Olodaterol is a once-daily LABA with a rapid onset and long duration of action and is approved for the treatment of COPD in Europe and US. It is delivered via a soft mist inhaler. Clinical trials showed that olodaterol improved lung function including peak and trough $\mathrm{FEV}_{1}$ and quality of life [57-59]. Adverse events with olodaterol were comparable to those of placebo.

Vilanterol is also a once-daily LABA with a rapid onset and long duration of action. However, so far, it is not available as a monotherapy. Vilanterol has been developed for combination inhalers with umeclidinium or fluticasone furoate.

(b)-3 Comparison between LAMAs and LABAs Because both LABAs and LAMAs are once-daily agents with a long acting duration, the question of which type is better for COPD patients may arise in the clinical setting. A randomized controlled trial has done the compared a once-daily LABA, indacaterol and a once-daily LAMA, tiotropium. A trial in which moderate-to-severe COPD patients were enrolled and observed over 26 weeks, showed that indacaterol significantly improved the trough $\mathrm{FEV}_{1}$ and at 12 weeks was superior to tiotropium, whereas indacaterol lost this superiority at 26 weeks, though the effects of indacaterol and tiotropium on the trough $\mathrm{FEV}_{1}$ were maintained in terms of differing from placebo [55]. This trial also showed that indacaterol improved dyspnoea (transitional dyspnoea index (TDI)) and health-related QOL (St. George's Respiratory Questionnaire (SGRQ)) better than tiotropium. In terms of reducing exacerbations, indacaterol did not appear superior to tiotropium. The two treatments were well tolerated and had similar adverse event profiles. Another randomized controlled trial in which moderate-to-severe COPD patients were enrolled and observed for 12 weeks, revealed that indacaterol significantly improved dyspnoea and health-related QOL, and reduced the use of rescue SABA compared to tiotropium, though there was no significant difference in $\mathrm{FEV}_{1}$ between indacaterol and tiotropium at 12 weeks [60]. There was a randomized controlled trial in which patients with severe COPD and a history of at least one moderate to severe exacerbation in the previous 12 months were enrolled. This trial showed that both indacaterol and tiotropium similarly improved the trough $\mathrm{FEV}_{1}$ as well as providing protection from exacerbations [61]. These trials suggested that once-daily indacaterol was at least as effective as a once-daily tiotropium in improving the clinical outcomes of patients with COPD.

(b)-4 Combination therapies Another type of long acting bronchodilator is additionally prescribed for COPD patients whose symptoms are not well-controlled with a single long-acting bronchodilator. A metaanalysis of five trials that assessed a combination therapy with a LAMA (tiotropium) plus a LABA (salmeterol, formoterol, or indacaterol) showed that a combination therapy provided only a small increase in the peak $\mathrm{FEV}_{1}$ and a slightly better quality of life compared to tiotropium alone [62]. No difference was noted in exacerbations, symptom scores, or serious adverse events.

Recently, a combination umeclidinium-vilanterol dry powder inhaler has been approved for once-daily use for COPD. Clinical trials showed that umeclidiniumvilanterol increased the trough $\mathrm{FEV}_{1}$ significantly more than umeclidinium, tiotropium or vilanterol monotherapy [63-66]. The combination inhaler also provided greater improvements in health-related QOL, and dyspnea scores compared with its mono-components and placebo [63]. The effectiveness of umeclidinium-vilanterol for the reduction of COPD exacerbations seemed to be similar to that of umeclidinium monotherapy [65].

Another once-daily dry powder inhaler containing the combination of indacaterol-glycopyrronium has been recently approved for COPD patients. The indacaterolglycopyrronium combination inhaler was found to be superior to monotherapy with glycopyrronium, indacaterol, or tiotropium in terms of trough $\mathrm{FEV}_{1}$ [67-69]. Indacaterol-glycopyrronium also decreased the use of rescue medication and risk of exacerbation, and improved the health-related QOL compared to monotherapy with glycopyrronium or tiotropium [68]. 


\section{(c) Methylxanthine}

Methylxantine is another option which may be considered as an additional therapy to bronchodilators and inhaled corticosteroids. Slow-release oral theophylline is usually used for COPD patients. Its bronchodilation effect is modest compared to inhaled bronchodilators. For effective bronchodilation, the plasma levels of theophylline needed to be in the 10 to $20 \mu \mathrm{g} / \mathrm{ml}$ range. Because theophylline can be toxic, close monitoring of the drug levels is required. In recent years, it has been reported that low-dose theophylline (about $5 \mu \mathrm{g} / \mathrm{ml}$ at plasma level) has anti-inflammatory effects in patients with COPD [70-73]. This anti-inflammatory effect is likely due to increasing HDAC2 expression and activity in the alveolar macrophages of patients with COPD [74-77].

\section{(2) Inhaled corticosteroids}

COPD is an inflammatory disorder characterized by both airway and systemic inflammation. Because inhaled corticosteroid (ICS) therapy appears to reduce the inflammation, it has been hypothesized that ICS therapy may improve clinical outcomes of COPD. A number of clinical trials, including the largest randomized controlled trial, found that ICS monotherapy decreased exacerbations and modestly slowed the progression of dyspnoea, but had minimal or no impact on lung function and survival in COPD patients [51, 78]. Therefore, ICS therapy should be added to basic treatment with bronchodilators for appropriate clinical phenotypes of COPD, not recommended as monotherapy for patients with stable COPD. These clinical phenotypes which need additional treatment of ICS include frequent exacerbators and patients with the overlap COPDasthma phenotype because lung inflammation is prominent in these phenotypes $[79,80]$.

Previous trials suggested that ICS could be considered as part of a combined therapy with bronchodilators for the inhibition of COPD exacerbations in severe/very severe patients. In one trial, salmeterol plus fluticasone significantly improved lung function, health-related QOL, and reduced the rate of exacerbations compared to placebo, salmeterol alone, or fluticasone alone [51]. In another clinical trial, 1323 COPD patients with stable, mostly severe COPD were enrolled and randomly assigned to receive salmeterol plus fluticasone or tiotropium alone for two years. There was no difference in the frequency of exacerbations, though salmeterol plus fluticasone reduced mortality and improved health-related QOL [81]. On the other hand, a subsequent analysis of this trial revealed that pneumonia was significantly more frequent in the salmeterol plus fluticasone group, despite the lower mortality [82]. It has also been shown that another twice-daily combination inhaler, budesonide/formoterol, increased the trough $\mathrm{FEV}_{1}$ with a significantly greater improvement than formoterol alone. The budesonide/formoterol group had a significantly prolonged time to first exacerbation versus the formoterol group and significantly greater improvements in secondary outcomes including symptom and health-related QOL [83, 84]. In addition to twice-daily combination inhalers, a once daily dry powder inhaler, containing fluticasone furoate and vilanterol, has been approved for the treatment of COPD in US. A multicenter, 24-week trial in which stable moderate-to-severe COPD patients were enrolled and randomly assigned to fluticasone-vilanterol, fluticasone, vilanterol, or placebo, showed that fluticasone-vilanterol modestly reduced the rates of moderate and severe exacerbation more than vilanterol alone [85]. The rate of pneumonia was increased in the fluticasone-vilanterol combination groups [85].

Because LAMAs have also been shown to prevent exacerbations [36, 39, 81] and two types of long-acting bronchodilators, LABA and LAMA, including a combination medication, are now prescribed for severe COPD patients, whether inhaled corticosteroids provided significant additional benefits to severe COPD patients who are treated with both two types of long-acting bronchodilators remained unclear. To address this question, the latest 12-month randomized-controlled trial studied 2485 severe COPD patients who had a history of exacerbations of COPD [86]. The patients received triple therapy consisting of tiotropium, salmeterol and fluticasone propionate during a 6 -week run-in period. The patients were then randomly assigned to continued triple therapy or withdrawal of fluticasone in three steps over a 12week period and were observed until week 52 . The results showed that the corticosteroid-withdrawal group did not show worse results in preventing exacerbations and improving dyspnea than the corticosteroidcontinuation group, though there were minor changes in the $\mathrm{FEV}_{1}$ and health status in the corticosteroidwithdrawal group at week 52. This report suggests the possibility that additional ICS may not be needed for reducing the risk of COPD exacerbations if the severe COPD patients are treated with LABA and LAMA, though it is also possible that the necessity of additional ICS may depend on a COPD phenotype which is more inflamed or not.

\section{(3) PDE-4 inhibitors}

Phosphodiesterase 4 (PDE-4) belongs to the cyclic nucleotide phosphodiesterase (PDE) family and has four gene families (A-D) [87]. As other PDEs, PDE-4 hydrolyzes cyclic adenosine monophosphate (cAMP). PDE-4 inhibitors block the hydrolysis of cAMP, resulting in increased levels of cAMP within the cells. It has been shown that inhibition of PDE-4 decreases inflammation and may promote airway smooth muscle relaxation. 
Roflumilast is an oral, PDE-4 inhibitor that is approved for COPD patients in the United States. Randomized controlled trials and a meta-analysis were performed to investigate the effects of PDE-4 inhibitors. A randomized controlled trial in which 3091 patients with COPD enrolled showed that Roflumilast significantly improved the trough FEV1 and decreased the rate of moderate to severe exacerbations during the 52 week trial [88]. In another trial, 933 patients with moderate to severe COPD were enrolled in and randomly assigned to roflumilast plus salmeterol or salmeterol alone and 743 patients were randomly assigned to roflumilast plus tiotropium or tiotropium alone [89]. Roflumilast significantly improved the trough $\mathrm{FEV}_{1}$, though such side effects of nausea, diarrhea, and weight loss were more frequent in the roflumilast groups. A meta-analysis of 23 randomized trials of roflumilast or cilomilast (another PDE-4 inhibitor) versus placebo found that treatment with a PDE-4 inhibitor modestly improved $\mathrm{FEV}_{1}$ and reduced the risk of exacerbations but had little effect on the healthrelated QOL [90]. Those studies suggest that oral PDE-4 inhibitors may be considered as an additional maintenance therapy for patients with severe COPD for preventing exacerbations. It has not been determined whether it provides additional benefits when combined with other medications (LABA and LAMA, or LABA and inhaled corticosteroids).

\section{Novel therapeutic targets for the future pharmacological therapy of COPD}

An important goal of COPD management is to reduce disease progression, prevent exacerbations, and reduce the mortality rate. Although recent advances in bronchodilators have enabled significant bronchodilation effects and improvement of the symptoms and quality of life, current therapies including long-acting bronchodilators fail to substantially reduce disease progression, mortality and the risk of exacerbations because bronchodilators don't have significantly anti-inflammatory effects. It has been shown that COPD is associated with chronic inflammation in peripheral airways and lung parenchyma as well as systemic inflammation causing comorbidities including cardiovascular diseases. Therefore, it is natural that effective anti-inflammatory treatment would be necessary for reducing the disease progression and the mortality of COPD patients. However, no current therapies including inhaled

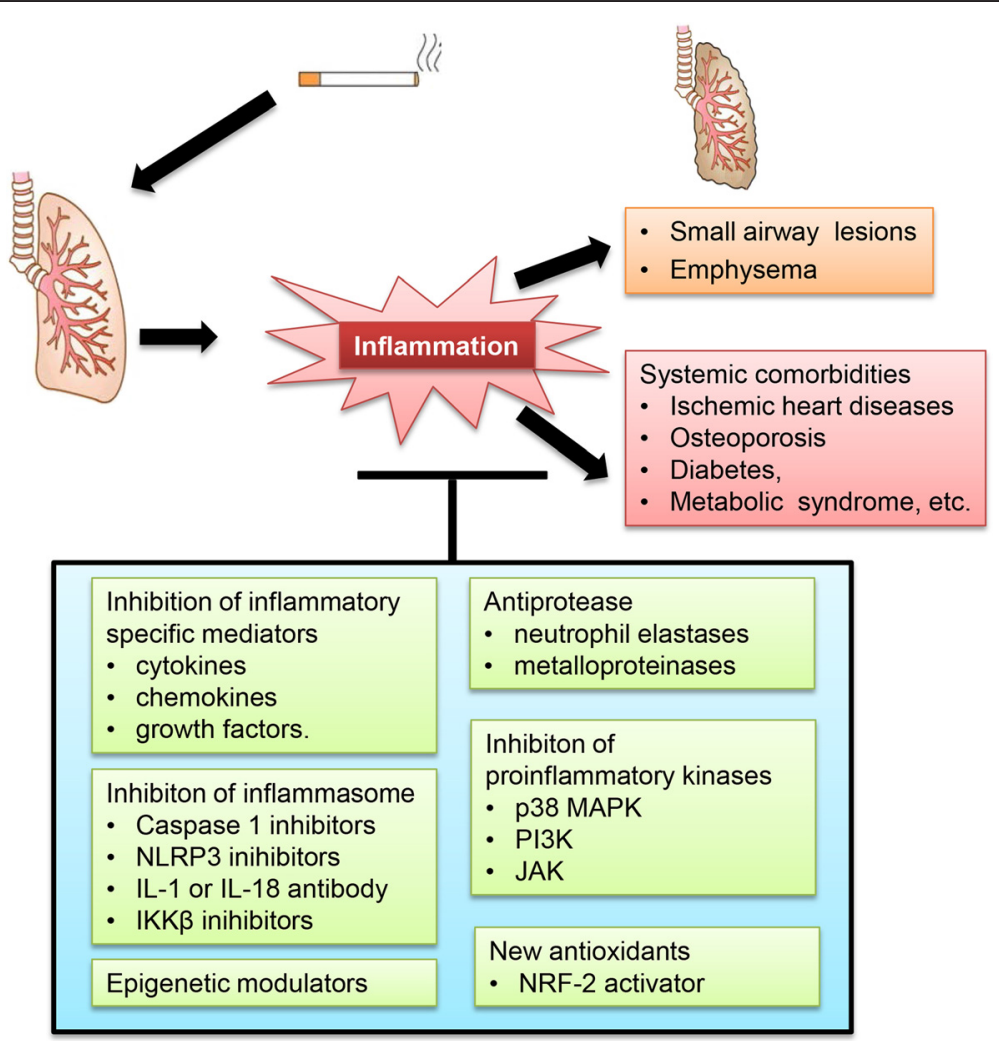

Fig. 1 Therapeutic targets for future pharmacological therapy of COPD. Recent advances in the research of underlying chronic inflammation provide new therapeutic targets for COPD patients. These possible therapeutic approaches include new antioxidants, inflammasome inhibitors, antagonists of cytokines or chemokines, inhibitors for pro-inflammatory kinase, antiproteases, and epigenetic modulation. IKK: inhibitor of NF-KB kinase; IL: interleukin; JAK: janus kinase; MAPK: mitogen-activated kinase; NRF-2: NF-E2-related factor; NLRP3: NOD-like receptor family, pyrin domain containing 3; PI3K: phosphoinositide 3-kinase 
corticosteroids and PDE-4 inhibitor is sufficiently effective to treat the underlying inflammation in COPD patients.

Recent advances in the research of the underlying inflammation have been suggesting new therapeutic targets for anti-inflammatory treatments in COPD patients (Fig. 1) [91]. These possible therapeutic approaches include new antioxidants, inflammasome inhibitors, antagonists of cytokines or chemokines, inhibitors for proinflammatory kinase, antiproteases, reversal of steroid resistance, and epigenetic modulation, some of which are undergoing clinical trials.

It has been suggested that there are barriers to establishing new therapeutic approaches for COPD [91, 92]. These barriers include incomplete understanding of the underlying mechanisms of COPD, lack of an appropriate animal model, the heterogeneity of the disease, lack of biomarkers for predicting therapeutic response and long-duration trials needed for demonstration of clinical efficacy. Moreover, it is also important to accomplish complete pathophysiological evaluation and characterization of COPD patients to select an appropriate treatment for each clinical phenotype of COPD in order to achieve the best management. Therefore, further investigations for better understanding of the biological and pathophysiological processes of COPD are needed to achieve the goal of COPD management.

\section{Conclusion}

Recent advances in the development of long-acting bronchodilators have enabled significantly improvements in the symptoms and lung function of COPD patients. These reagents also reduce the risk of exacerbation and the rate of the progression of airflow limitation to some extent. To establish novel COPD therapies that can substantially reduce disease progression, mortality and the comorbidities, new therapeutic approaches that can resolve the underlying chronic inflammation and lung pathophysiological modifications in COPD are needed, and are being investigated.

\section{Abbreviations \\ CAMP: cyclic adenosine monophosphate; COPD: Chronic obstructive pulmonary disease; DPI: Dry powder inhaler; FEV ${ }_{1}$ : Forced expiratory volume in one second; FVC: Forced vital capacity; ICS: Inhaled corticosteroid; LABA: Long-acting $\beta 2$-agonist; LAMA: Long-acting muscarinic antagonists; MDI: Metered-dose inhaler; QOL: Quality of life; SABA: short-acting $\beta 2-$ agonist; SGRQ: St. George's respiratory questionnaire; SMI: Soft mist inhaler; TDI: Transition dyspnea index.}

\section{Competing interests}

The authors declare that they have no competing interests.

\section{Authors' contributions}

Both authors contributed to writing the manuscript. Both authors read and approved the final version of the manuscript.

Received: 8 April 2015 Accepted: 4 August 2015

Published online: 02 October 2015

\section{References}

1. Halbert RJ, Natoli JL, Gano A, Badamgarav E, Buist AS, Mannino DM. Global burden of COPD: systematic review and meta-analysis. Eur Respir J. 2006;28:523-32.

2. Ford ES, Croft JB, Mannino DM, Wheaton AG, Zhang X, Giles WH. COPD surveillance-United States, 1999-2011. Chest. 2013;144:284-305.

3. Menezes AM, Perez-Padilla R, Jardim JR, Muino A, Lopez MV, Valdivia G, et al. Chronic obstructive pulmonary disease in five Latin American cities (the PLATINO study): a prevalence study. Lancet. 2005;366:1875-81.

4. Buist AS, McBurnie MA, Vollmer WM, Gillespie S, Burney P, Mannino DM, et al. International variation in the prevalence of COPD (the BOLD Study): a population-based prevalence study. Lancet. 2007;370:741-50.

5. Fukuchi $Y$, Nishimura $M$, Ichinose $M$, Adachi M, Nagai A, Kuriyama T, et al. COPD in Japan: the Nippon COPD Epidemiology study. Respirology. 2004;9:458-65.

6. Lopez AD, Shibuya K, Rao C, Mathers CD, Hansell AL, Held LS, et al. Chronic obstructive pulmonary disease: current burden and future projections. Eur Respir J. 2006;27:397-412.

7. Hogg JC. Pathophysiology of airflow limitation in chronic obstructive pulmonary disease. Lancet. 2004;364:709-21.

8. Hogg JC, Chu F, Utokaparch S, Woods R, Elliott WM, Buzatu L, et al. The nature of small-airway obstruction in chronic obstructive pulmonary disease. N Engl J Med. 2004;350:2645-53.

9. O'Donnell DE, Webb KA. Exertional breathlessness in patients with chronic airflow limitation. The role of lung hyperinflation. Am Rev Respir Dis. 1993;148:1351-7.

10. O'Donnell DE, Revill SM, Webb KA. Dynamic hyperinflation and exercise intolerance in chronic obstructive pulmonary disease. Am J Respir Crit Care Med. 2001;164:770-7.

11. Hogg JC, Macklem PT, Thurlbeck WM. Site and nature of airway obstruction in chronic obstructive lung disease. N Engl J Med. 1968;278:1355-60.

12. McDonough JE, Yuan R, Suzuki M, Seyednejad N, Elliott WM, Sanchez PG, et al. Small-airway obstruction and emphysema in chronic obstructive pulmonary disease. New Engl J Med. 2011;365:1567-75.

13. Lai $H$, Rogers DF. New pharmacotherapy for airway mucus hypersecretion in asthma and COPD: targeting intracellular signaling pathways. J Aerosol Med Pulm Drug Deliv. 2010;23:219-31.

14. Braido F, Baiardini I, Scichilone N, Sorino C, Di Marco F, Corsico A, et al. Disability in moderate chronic obstructive pulmonary disease: prevalence, burden and assessment - results from a real-life study. Respiration. 2015;89:100-6.

15. Barnes PJ, Celli BR. Systemic manifestations and comorbidities of COPD. Eur Respir J. 2009;33:1165-85.

16. Agusti AG, Noguera A, Sauleda J, Sala E, Pons J, Busquets X. Systemic effects of chronic obstructive pulmonary disease. Eur Respir J. 2003;21:347-60.

17. Soriano JB, Visick GT, Muellerova H, Payvandi N, Hansell AL. Patterns of comorbidities in newly diagnosed COPD and asthma in primary care. Chest. 2005;128:2099-107.

18. Belman MJ, Botnick WC, Shin JW. Inhaled bronchodilators reduce dynamic hyperinflation during exercise in patients with chronic obstructive pulmonary disease. Am J Respir Crit Care Med. 1996;153:967-75.

19. Santus P, Radovanovic D, Henchi S, Di Marco F, Centanni S, D'Angelo E, et al. Assessment of acute bronchodilator effects from specific airway resistance changes in stable COPD patients. Respir Physiol Neurobiol. 2014;197:36-45.

20. Scichilone N, Benfante A, Bocchino M, Braido F, Paggiaro P, Papi A, et al. Which factors affect the choice of the inhaler in chronic obstructive respiratory diseases? Pulm Pharmacol Ther. 2015;31:63-7.

21. Johnson M. The beta-adrenoceptor. Am J Respir Crit Care Med. 1998;158:S146-153.

22. Roux E, Molimard M, Savineau JP, Marthan R. Muscarinic stimulation of airway smooth muscle cells. Gen Pharmacol. 1998;31:349-56.

23. Essayan DM. Cyclic nucleotide phosphodiesterases. The Journal of allergy and clinical immunology. 2001;108:671-80.

24. Ofir D, Laveneziana P, Webb KA, Lam YM, O'Donnell DE. Mechanisms of dyspnea during cycle exercise in symptomatic patients with GOLD stage I chronic obstructive pulmonary disease. Am J Respir Crit Care Med. 2008;177:622-9.

25. O'Donnell DE, Laveneziana P, Ora J, Webb KA, Lam YM, Ofir D. Evaluation of acute bronchodilator reversibility in patients with symptoms of GOLD stage I COPD. Thorax. 2009;64:216-23. 
26. Bone R, Boyars M, Braun SR, Buist S, Campbell S, Chick T, et al. In chronic obstructive pulmonary disease, a combination of ipratropium and albuterol is more effective than either agent alone. An 85-day multicenter trial. COMBIVENT Inhalation Aerosol Study Group. Chest 1994, 105:1411-1419.

27. Vogelmeier C, Banerji D. NVA237, a long-acting muscarinic antagonist, as an emerging therapy for chronic obstructive pulmonary disease. Ther adv Respir Dis. 2011;5:163-73.

28. Gavalda A, Miralpeix M, Ramos I, Otal R, Carreno C, Vinals M, et al. Characterization of aclidinium bromide, a novel inhaled muscarinic antagonist, with long duration of action and a favorable pharmacological profile. J Pharmacol Exp Ther. 2009;331:740-51.

29. Gross NJ. Tiotropium bromide. Chest. 2004;126:1946-53.

30. Casaburi R, Mahler DA, Jones PW, Wanner A, San PG, ZuWallack RL, et al. A long-term evaluation of once-daily inhaled tiotropium in chronic obstructive pulmonary disease. Eur Respir J. 2002;19:217-24.

31. Donohue JF, van Noord JA, Bateman ED, Langley SJ, Lee A, Witek Jr TJ, et al. A 6-month, placebo-controlled study comparing lung function and health status changes in COPD patients treated with tiotropium or salmeterol. Chest. 2002;122:47-55.

32. Dusser $D$, Bravo ML, lacono P. The effect of tiotropium on exacerbations and airflow in patients with COPD. Eur Respir J. 2006:27:547-55.

33. Niewoehner DE, Rice K, Cote C, Paulson D, Cooper Jr JA, Korducki L, et al. Prevention of exacerbations of chronic obstructive pulmonary disease with tiotropium, a once-daily inhaled anticholinergic bronchodilator: a randomized trial. Ann Intern Med. 2005;143:317-26.

34. van Noord JA, Bantje TA, Eland ME, Korducki L, Cornelissen PJ. A randomised controlled comparison of tiotropium nd ipratropium in the treatment of chronic obstructive pulmonary disease. The Dutch Tiotropium Study Group Thorax. 2000;55:289-94.

35. Vincken W, van Noord JA, Greefhorst AP, Bantje TA, Kesten S, Korducki L, et al. Improved health outcomes in patients with COPD during 1 yr's treatment with tiotropium. Eur Respir J. 2002;19:209-16.

36. Vogelmeier C, Hederer B, Glaab T, Schmidt H, Rutten-van Molken MP, Beeh $\mathrm{KM}$, et al. Tiotropium versus salmeterol for the prevention of exacerbations of COPD. N Engl J Med. 2011;364:1093-103.

37. Decramer M, Celli B, Kesten S, Lystig T, Mehra S, Tashkin DP. Effect of tiotropium on outcomes in patients with moderate chronic obstructive pulmonary disease (UPLIFT): a prespecified subgroup analysis of a randomised controlled trial. Lancet. 2009;374:1171-8.

38. Troosters T, Celli B, Lystig T, Kesten S, Mehra S, Tashkin DP, et al. Tiotropium as a first maintenance drug in COPD: secondary analysis of the UPLIFT trial. Eur Respir J. 2010:36:65-73.

39. Tashkin DP, Celli BR, Decramer M, Lystig T, Liu D, Kesten S. Efficacy of tiotropium in COPD patients with FEV $1>/=60 \%$ participating in the UPLIFT(R) trial. COPD. 2012;9:289-96.

40. Singh S, Loke YK, Enright PL, Furberg CD. Mortality associated with tiotropium mist inhaler in patients with chronic obstructive pulmonary disease: systematic review and meta-analysis of randomised controlled trials. BMJ. 2011:342:d3215.

41. Dong YH, Lin HH, Shau WY, Wu YC, Chang CH, Lai MS. Comparative safety of inhaled medications in patients with chronic obstructive pulmonary disease: systematic review and mixed treatment comparison meta-analysis of randomised controlled trials. Thorax. 2013;68:48-56.

42. Tashkin DP, Celli B, Senn S, Burkhart D, Kesten S, Menjoge S, et al. A 4-year trial of tiotropium in chronic obstructive pulmonary disease. N Engl J Med. 2008;359:1543-54.

43. Wise RA, Anzueto A, Cotton D, Dahl R, Devins T, Disse B, et al. Tiotropium Respimat inhaler and the risk of death in COPD. N Engl J Med. 2013;369:1491-501.

44. D'Urzo A, Ferguson GT, van Noord JA, Hirata K, Martin C, Horton R, et al. Efficacy and safety of once-daily NVA237 in patients with moderate-tosevere COPD: the GLOW1 trial. Respir Res. 2011;12:156.

45. Kerwin E, Hebert J, Gallagher N, Martin C, Overend T, Alagappan VK, et al. Efficacy and safety of NVA237 versus placebo and tiotropium in patients with COPD: the GLOW2 study. Eur Respir J. 2012;40:1106-14.

46. Jones PW, Singh D, Bateman ED, Agusti A, Lamarca R, de Miquel G, et al. Efficacy and safety of twice-daily aclidinium bromide in COPD patients: the ATTAIN study. Eur Respir J. 2012:40:830-6.

47. Kerwin EM, D'Urzo AD, Gelb AF, Lakkis H, Garcia Gil E, Caracta CF. Efficacy and safety of a 12-week treatment with twice-daily aclidinium bromide in COPD patients (ACCORD COPD I). COPD. 2012;9:90-101.
48. Decramer M, Maltais F, Feldman G, Brooks J, Harris S, Mehta R, et al. Bronchodilation of umeclidinium, a new long-acting muscarinic antagonist, in COPD patients. Respir Physiol Neurobiol. 2013;185:393-9.

49. Mahler DA, Donohue JF, Barbee RA, Goldman MD, Gross NJ, Wisniewski ME, et al. Efficacy of salmeterol xinafoate in the treatment of COPD. Chest. 1999;115:957-65.

50. Rennard SI, Anderson W, ZuWallack R, Broughton J, Bailey W, Friedman M, et al. Use of a long-acting inhaled beta2-adrenergic agonist, salmeterol xinafoate, in patients with chronic obstructive pulmonary disease. Am J Respir Crit Care Med. 2001;163:1087-92.

51. Calverley PM, Anderson JA, Celli B, Ferguson GT, Jenkins C, Jones PW, et al. Salmeterol and fluticasone propionate and survival in chronic obstructive pulmonary disease. N Engl J Med. 2007;356:775-89.

52. Dahl R, Greefhorst LA, Nowak D, Nonikov V, Byrne AM, Thomson MH, et al. Inhaled formoterol dry powder versus ipratropium bromide in chronic obstructive pulmonary disease. Am J Respir Crit Care Med. 2001;164:778-84.

53. Lombardi D, Cuenoud B, Kramer SD. Lipid membrane interactions of indacaterol and salmeterol: do they influence their pharmacological properties? Eur J Pharm Sci. 2009;38:533-47.

54. Dahl R, Chung KF, Buhl R, Magnussen $H$, Nonikov V, Jack D, et al. Efficacy of a new once-daily long-acting inhaled beta2-agonist indacaterol versus twice-daily formoterol in COPD. Thorax. 2010;65:473-9.

55. Donohue JF, Fogarty C, Lotvall J, Mahler DA, Worth H, Yorgancioglu A, et al. Once-daily bronchodilators for chronic obstructive pulmonary disease: indacaterol versus tiotropium. Am J Respir Crit Care Med. 2010;182:155-62.

56. Kornmann O, Dahl R, Centanni S, Dogra A, Owen R, Lassen C, et al. Oncedaily indacaterol versus twice-daily salmeterol for COPD: a placebocontrolled comparison. Eur Respir J. 2011;37:273-9.

57. Koch A, Pizzichini E, Hamilton A, Hart L, Korducki L, De Salvo MC, et al. Lung function efficacy and symptomatic benefit of olodaterol once daily delivered via Respimat $(R)$ versus placebo and formoterol twice daily in patients with GOLD 2-4 COPD: results from two replicate 48-week studies. Int J Chron Obstruct Pulmon Dis. 2014;9:697-714.

58. ZuWallack R, Allen L, Hernandez G, Ting N, Abrahams R. Efficacy and safety of combining olodaterol Respimat((R)) and tiotropium HandiHaler((R)) in patients with COPD: results of two randomized, double-blind, activecontrolled studies. Int J Chron Obstruct Pulmon Dis. 2014;9:1133-44.

59. Ferguson GT, Feldman GJ, Hofbauer P, Hamilton A, Allen L, Korducki L, et al. Efficacy and safety of olodaterol once daily delivered via Respimat(R) in patients with GOLD 2-4 COPD: results from two replicate 48-week studies. Int J Chron Obstruct Pulmon Dis. 2014;9:629-45.

60. Buhl R, Dunn LJ, Disdier C, Lassen C, Amos C, Henley M, et al. Blinded 12week comparison of once-daily indacaterol and tiotropium in COPD. Eur Respir J. 2011;38:797-803.

61. Decramer ML, Chapman KR, Dahl R, Frith P, Devouassoux G, Fritscher C, et al. Once-daily indacaterol versus tiotropium for patients with severe chronic obstructive pulmonary disease (INVIGORATE): a randomised, blinded, parallelgroup study. The Lancet Respiratory medicine. 2013;1:524-33.

62. Karner C, Cates CJ. Long-acting beta(2)-agonist in addition to tiotropium versus either tiotropium or long-acting beta(2)-agonist alone for chronic obstructive pulmonary disease. Cochrane Database Syst Rev. 2012;4, CD008989.

63. Celli B, Crater G, Kilbride S, Mehta R, Tabberer M, Kalberg CJ, et al. Oncedaily umeclidinium/vilanterol 125/25 mcg in COPD: a randomized, controlled study. Chest. 2014.

64. Donohue JF, Maleki-Yazdi MR, Kilbride S, Mehta R, Kalberg C, Church A Efficacy and safety of once-daily umeclidinium/vilanterol $62.5 / 25 \mathrm{mcg}$ in COPD. Respir Med. 2013;107:1538-46.

65. Donohue JF, Niewoehner D, Brooks J, O'Dell D, Church A. Safety and tolerability of once-daily umeclidinium/vilanterol 125/25 mcg and umeclidinium $125 \mathrm{mcg}$ in patients with chronic obstructive pulmonary disease: results from a 52-week, randomized, double-blind, placebocontrolled study. Respir Res. 2014;15:78.

66. Maleki-Yazdi MR, Kaelin T, Richard N, Zvarich M, Church A. Efficacy and safety of umeclidinium/vilanterol $62.5 / 25 \mathrm{mcg}$ and tiotropium $18 \mathrm{mcg}$ in chronic obstructive pulmonary disease: results of a 24-week, randomized, controlled trial. Respir Med. 2014;108:1752-60.

67. Rodrigo GJ, Plaza V. Efficacy and safety of indacaterol and Glycopyrronium in COPD: an update. Chest. 2014;146, e75.

68. Rodrigo GJ, Plaza V. Efficacy and safety of a fixed-dose combination of indacaterol and Glycopyrronium for the treatment of COPD: a systematic review. Chest. 2014;146:309-17. 
69. Vincken W, Aumann J, Chen H, Henley M, McBryan D, Goyal P. Efficacy and safety of coadministration of once-daily indacaterol and glycopyrronium versus indacaterol alone in COPD patients: the GLOW6 study. Int J Chron Obstruct Pulmon Dis. 2014;9:215-28.

70. Barnes PJ. Theophylline for COPD. Thorax. 2006;61:742-4.

71. Culpitt SV, de Matos C, Russell RE, Donnelly LE, Rogers DF, Barnes PJ. Effect of theophylline on induced sputum inflammatory indices and neutrophil chemotaxis in chronic obstructive pulmonary disease. Am J Respir Crit Care Med. 2002;165:1371-6.

72. Hirano T, Yamagata T, Gohda M, Yamagata Y, Ichikawa T, Yanagisawa S, et al. Inhibition of reactive nitrogen species production in COPD airways: comparison of inhaled corticosteroid and oral theophylline. Thorax. 2006;61:761-6.

73. Kobayashi M, Nasuhara Y, Betsuyaku T, Shibuya E, Tanino Y, Tanino M, et al. Effect of low-dose theophylline on airway inflammation in COPD. Respirology. 2004;9:249-54

74. Ito K, Lim S, Caramori G, Cosio B, Chung KF, Adcock IM, et al. A molecular mechanism of action of theophylline: Induction of histone deacetylase activity to decrease inflammatory gene expression. Proc Nat Acad Sci U S A. 2002;99:8921-6.

75. Ito K, Ito M, Elliott WM, Cosio B, Caramori G, Kon OM, et al. Decreased histone deacetylase activity in chronic obstructive pulmonary disease. $\mathrm{N}$ Engl J Med. 2005;352:1967-76.

76. Cosio BG, Tsaprouni L, Ito K, Jazrawi E, Adcock IM, Barnes PJ. Theophylline restores histone deacetylase activity and steroid responses in COPD macrophages. J Exp Med. 2004;200:689-95.

77. Ito K, Yamamura S, Essilfie-Quaye S, Cosio B, Ito M, Barnes PJ, et al. Histone deacetylase 2-mediated deacetylation of the glucocorticoid receptor enables NF-kappaB suppression. J Exp Med. 2006;203:7-13.

78. Celli BR, Thomas NE, Anderson JA, Ferguson GT, Jenkins CR, Jones PW, et al. Effect of pharmacotherapy on rate of decline of lung function in chronic obstructive pulmonary disease: results from the TORCH study. Am J Respir Crit Care Med. 2008;178:332-8.

79. Miravitlles M, Soler-Cataluna JJ, Calle M, Soriano JB. Treatment of COPD by clinical phenotypes: putting old evidence into clinical practice. Eur Respir J. 2013;41:1252-6.

80. Bettoncelli G, Blasi F, Brusasco V, Centanni S, Corrado A, De Benedetto F, De Michele F, Di Maria GU, Donner CF, Falcone F, et al.: The clinical and integrated management of COPD. An official document of AIMAR (Interdisciplinary Association for Research in Lung Disease), AIPO (Italian Association of Hospital Pulmonologists), SIMER (Italian Society of Respiratory Medicine), SIMG (Italian Society of General Medicine). Multidisciplinary respiratory medicine 2014, 9:25.

81. Wedzicha JA, Calverley PM, Seemungal TA, Hagan G, Ansari Z, Stockley RA. The prevention of chronic obstructive pulmonary disease exacerbations by salmeterol/fluticasone propionate or tiotropium bromide. Am J Respir Crit Care Med. 2008;177:19-26.

82. Calverley PM, Stockley RA, Seemungal TA, Hagan G, Willits LR, Riley JH, et al. Reported pneumonia in patients with COPD: findings from the INSPIRE study. Chest. 2011;139:505-12.

83. Fukuchi Y, Samoro R, Fassakhov R, Taniguchi H, Ekelund J, Carlsson LG, et al. Budesonide/formoterol via Turbuhaler(R) versus formoterol via Turbuhaler(R) in patients with moderate to severe chronic obstructive pulmonary disease: phase III multinational study results. Respirology. 2013;18:866-73.

84. Larsson K, Janson C, Lisspers K, Jorgensen L, Stratelis G, Telg G, et al. Combination of budesonide/formoterol more effective than fluticasone/ salmeterol in preventing exacerbations in chronic obstructive pulmonary disease: the PATHOS study. J Intern Med. 2013;273:584-94.

85. Martinez FJ, Boscia J, Feldman G, Scott-Wilson C, Kilbride S, Fabbri L, et al. Fluticasone furoate/vilanterol (100/25; 200/25 mug) improves lung function in COPD: a randomised trial. Respir Med. 2013;107:550-9.

86. Magnussen H, Disse B, Rodriguez-Roisin R, Kirsten A, Watz H, Tetzlaff K, et al. Withdrawal of inhaled glucocorticoids and exacerbations of COPD. N Engl J Med. 2014:371:1285-94.

87. Spina D. PDE4 inhibitors: current status. Br J Pharmacol. 2008;155:308-15.

88. Calverley PM, Rabe KF, Goehring UM, Kristiansen S, Fabbri LM, Martinez FJ. Roflumilast in symptomatic chronic obstructive pulmonary disease: two randomised clinical trials. Lancet. 2009;374:685-94.

89. Fabbri LM, Calverley PM, Izquierdo-Alonso JL, Bundschuh DS, Brose M, Martinez FJ, et al. Roflumilast in moderate-to-severe chronic obstructive pulmonary disease treated with longacting bronchodilators: two randomised clinical trials. Lancet. 2009;374:695-703.

90. Chong J, Poole P, Leung B, Black PN: Phosphodiesterase 4 inhibitors for chronic obstructive pulmonary disease. Cochrane Database Syst Rev. 2011. doi:10.1002/14651858.CD002309.pub3.

91. Barnes PJ. New anti-inflammatory targets for chronic obstructive pulmonary disease. Nature reviews Drug discovery. 2013;12:543-59.

92. Martinez FJ, Donohue JF, Rennard SI. The future of chronic obstructive pulmonary disease treatment-difficulties of and barriers to drug development. Lancet. 2011;378:1027-37.

\section{Submit your next manuscript to BioMed Central and take full advantage of:}

- Convenient online submission

- Thorough peer review

- No space constraints or color figure charges

- Immediate publication on acceptance

- Inclusion in PubMed, CAS, Scopus and Google Scholar

- Research which is freely available for redistribution 